\title{
Pasung: Physical restraint and confinement of the mentally ill in the community
} Harry Minas*1 and Hervita Diatri²

Address: ${ }^{1}$ Centre for International mental Health, Melbourne School of Population Health, The University of Melbourne, Parkville, Victoria 3010, Australia and ${ }^{2}$ Department of Psychiatry, University of Indonesia, Kimia II No. 35, Center Jakarta, 10430, Indonesia

Email: Harry Minas* - h.minas@unimelb.edu.au; Hervita Diatri - hervita94@yahoo.com

* Corresponding author

Published: 16 June 2008

International Journal of Mental Health Systems 2008, 2:8 doi:10.1 I86/I752-4458-2-8

This article is available from: http://www.ijmhs.com/content/2/I/8

(c) 2008 Minas and Diatri; licensee BioMed Central Ltd.

This is an Open Access article distributed under the terms of the Creative Commons Attribution License (http://creativecommons.org/licenses/by/2.0), which permits unrestricted use, distribution, and reproduction in any medium, provided the original work is properly cited.

\begin{abstract}
Background: Physical restraint and confinement (pasung) by families of people with mental illness is known to occur in many parts of the world but has attracted limited investigation. This preliminary observational study was carried out on Samosir Island in Sumatra, Indonesia, to investigate the nature of such restraint and confinement, the clinical characteristics of people restrained, and the reasons given by families and communities for applying such restraint.

Methods: The research method was cross-sectional observational research in a natural setting, carried out during a six-month period of working as the only psychiatrist in a remote district.

Results: Fifteen cases of pasung, approximately even numbers of males and females and almost all with a diagnosis of schizophrenia were identified. Duration of restraint ranged from two to 21 years.

Discussion and Conclusion: The provision of basic community mental health services, where there were none before, enabled the majority of the people who had been restrained to receive psychiatric treatment and to be released from pasung.
\end{abstract}

\section{Background}

"All persons with a mental illness... shall be treated with humanity and respect for the inherent dignity of the human person."

UN Resolution 46/119[1]

In Indonesia the term pasung refers to the physical restraint or confinement of "criminals, crazy and dangerously aggressive people." [2]

For six months during 2006 HD worked as the only psychiatrist on Samosir Island in North Sumatra. Nearly the size of Singapore, Samosir has a population of approximately 130,000 . It is the world's largest island within an island, located in Lake Toba, in the planet's largest caldera (collapsed volcano formation). Although Samosir is a popular tourist destination most of the population, predominantly ethnic Batak, is rural and poor.

Samosir has a reasonably well-developed district health service with a district general hospital and 11 community health centres (puskesmas), each with two or three doctors.

However, like most rural districts in Indonesia, Samosir has no mental health budget or mental health service. The 
nearest available mental health service is the mental hospital in Medan, approximately six hours travel by boat and then by road.

Soon after arriving on Samosir HD became aware of cases of pasung in this small but widely dispersed community. The objective of this work was to locate all cases of pasung on Samosir Island, to investigate the circumstances of restraint, and to release from restraint as many as was possible.

\section{Methods}

The research method was cross-sectional observational research in a natural setting, carried out during a sixmonth period of working as the only psychiatrist in Samosir, with some limited follow-up.

Case finding was through discussion with doctors and other clinical staff in the 11 puskesmas, visiting villages and having discussions with village heads and other key members of village communities.

Diagnosis, and the other information reported in this paper, was based on interviews with the person who was restrained, with members of the family when they were available and other members of the village communities who could give relevant information. In those cases where release from pasung was possible and treatment was initiated limited follow-up information is available from repeat visits to the home village.

\section{Results}

Over the course of six months 15 cases of pasung were identified. Figures 1 and 2 show typical forms of restraint, with iron shackles and wooden stocks. A summary of the characteristics of the cases found is presented in Table 1.

Of the 15 cases eight were male and seven female, ranging in age from 25 to 56 years. In 13 of the cases a diagnosis of schizophrenia was made. In one case (case 12) the diagnosis was personality change and interictal hallucinations due to probable temporal lobe epilepsy, and in another (case 13) the diagnosis was dementia of unknown aetiology with behavioural disturbance. Duration of illness ranged from three to more than 25 years. Somewhat surprisingly nine of the 15 cases had had previous psychiatric treatment. The commonest reason given for the discontinuation of treatment was that it was unaffordable. The major component of the cost of treatment that could not be afforded was the cost of travel, since the nearest place at which psychiatric treatment was available was in the city of Medan, six hours away by boat and then road.

The most common form of pasung was confinement in a small room or hut. In one case the hut was in the middle of the family's rice field some ten minutes walk from the house. In all cases the family (sometimes with the support of other members of the community) had initiated and was responsible for maintaining the pasung. Duration of pasung ranged from two to 21 years.

The reasons given for pasung were often multiple, including violence, concern about the person wandering off or running away and coming to harm, concern about possibility of suicide, and the unavailability of a caregiver. In seven cases - six male and one female - the primary reason was a history of, or concern about possible, violence. A 26 year old man had attacked his father with a knife, and a 35 year old man had attempted to strangle a priest. A 27 year old man had murdered three people and had set fire to the family house and to the village church. During the six months that he was in prison the prison authorities realised he was mentally ill at which point he was returned to his family, with no formal psychiatric assessment or treatment.

Following assessment of risk, provision of information to the family and to the village head and the village community, initiation of treatment, and provision of basic education to the puskesmas doctors and nurses, it was determined that thirteen of the 15 cases could be treated and released from pasung (Figure 3). In six of the 13 cases that were treated treatment was initiated during a short hospital admission and then continued after discharge. In seven cases outpatient treatment was deemed to be appropriate. At follow-up, at the end of the six month period, only two of the 13 cases had been again restrained.

\section{Discussion}

Physical restraint of people with mental illness has a long and inglorious history. Philippe Pinel is credited with having released the mentally ill from their chains at the Bicêtre and the Salpetrière hospitals in Paris at the end of the $18^{\text {th }}$ century. And yet physical restraint has continued in mental hospitals, [3] in religious shrines and healing sanctuaries, [4-8] and other settings in many parts of the world. [8-14] Such restraint, including shackles, rope, stocks,[15] cages,[11] and being locked in confined spaces, is applied to men, [16-18] women[19] and children[20]. The practice seems to have aroused little human rights concern, except when mentally ill people in chains have died.[4,17,21]

Several findings from this study should be highlighted. First, it is families that are responsible for restraint and confinement. The main motivations for the practice are to prevent harm to others and to the ill person. Second, more than half of the ill people had had previous psychiatric treatment that had been discontinued, almost always because of the unavailability of affordable treatment. 


\begin{tabular}{|c|c|c|c|c|c|c|c|c|c|c|}
\hline $\begin{array}{l}\text { Case } \\
\text { Number }\end{array}$ & $\begin{array}{l}\text { Male/ } \\
\text { Female }\end{array}$ & Age (Years) & Diagnosis & $\begin{array}{c}\text { Duration of } \\
\text { illness (years) }\end{array}$ & $\begin{array}{c}\text { Previous } \\
\text { psychiatric } \\
\text { treatment } \\
(\text { Yes/No) }\end{array}$ & $\begin{array}{l}\text { Type of } \\
\text { pasung }\end{array}$ & $\begin{array}{l}\text { Duration in } \\
\text { pasung } \\
\text { (years) }\end{array}$ & Initiator & Reason for pasung & $\begin{array}{l}\text { Released? } \\
\text { (Yes/No) }\end{array}$ \\
\hline 1 & $M$ & 56 & $\begin{array}{l}\text { Depression, post- } \\
\text { schizophrenia }\end{array}$ & $>25$ & yes & wooden stocks & 21 & $\begin{array}{l}\text { Family and } \\
\text { community }\end{array}$ & $\begin{array}{l}\text { History of violence; treatment not } \\
\text { affordable }\end{array}$ & yes \\
\hline 2 & M & 26 & Schizophrenia & 5 & yes & $\begin{array}{l}\text { confined in a } \\
\text { small room }\end{array}$ & 5 & Family & $\begin{array}{l}\text { Treatment not affordable; fear of } \\
\text { violence }\end{array}$ & yes \\
\hline 3 & $M$ & 28 & $\begin{array}{l}\text { Schizophrenia and } \\
\text { suspected mild } \\
\text { mental retardation }\end{array}$ & 10 & yes & tied with rope & 10 & Family & $\begin{array}{l}\text { Treatment not affordable; fear of } \\
\text { violence; fear that he will get lost and } \\
\text { come to harm }\end{array}$ & yes \\
\hline 4 & M & 27 & Schizophrenia & 12 & no & chained & 10 & $\begin{array}{l}\text { Family and } \\
\text { community }\end{array}$ & $\begin{array}{l}\text { Setting fire to family house and } \\
\text { church; history of violence; } \\
\text { considered dangerous }\end{array}$ & no \\
\hline 5 & $\mathrm{~F}$ & 45 & Schizophrenia & $>15$ & no & $\begin{array}{l}\text { confined in a } \\
\text { small room }\end{array}$ & 4 & family & $\begin{array}{l}\text { Fear that she will run away and come } \\
\text { to harm }\end{array}$ & yes \\
\hline 6 & $\mathrm{~F}$ & 55 & Schizophrenia & 10 & yes & $\begin{array}{l}\text { confined in a } \\
\text { small room }\end{array}$ & 2 & $\begin{array}{l}\text { family-her } \\
\text { children }\end{array}$ & $\begin{array}{l}\text { Treatment not affordable; fear that } \\
\text { she will run away; fear of possibility } \\
\text { of suicide }\end{array}$ & yes \\
\hline 7 & $\mathrm{~F}$ & 41 & Schizophrenia & 16 & no & tied with rope & 16 & family & $\begin{array}{l}\text { Treatment not affordable; fear that } \\
\text { she will run away and come to harm; } \\
\text { inappropriate sexual behaviour; no- } \\
\text { one to look after her }\end{array}$ & yes \\
\hline 8 & $\mathrm{~F}$ & 32 & Schizophrenia & 5 & yes & $\begin{array}{l}\text { confined in a } \\
\text { small room }\end{array}$ & 3 & family & $\begin{array}{l}\text { Treatment not affordable; fear that } \\
\text { she will run away and come to harm; } \\
\text { no-one to look after her }\end{array}$ & yes \\
\hline 9 & $M$ & 27 & Schizophrenia & 3 & yes & $\begin{array}{l}\text { confined in a } \\
\text { small room }\end{array}$ & 2 & family & $\begin{array}{l}\text { History of violence; treatment not } \\
\text { affordable; no-one to look after him }\end{array}$ & yes \\
\hline 10 & $M$ & 25 & Schizophrenia & 5 & no & $\begin{array}{l}\text { confined in a } \\
\text { small room }\end{array}$ & 5 & family & History of violence & yes \\
\hline 11 & $\mathrm{~F}$ & 25 & $\begin{array}{l}\text { Schizoaffective } \\
\text { disorder }\end{array}$ & 5 & no & $\begin{array}{l}\text { confined in a } \\
\text { small stall in the } \\
\text { rice-field }\end{array}$ & 5 & family & $\begin{array}{l}\text { Treatment not affordable; fear that } \\
\text { she will run away and come to harm; } \\
\text { wasting money; inappropriate sexual } \\
\text { behaviour }\end{array}$ & yes \\
\hline 12 & $\mathrm{~F}$ & 56 & $\begin{array}{l}\text { Temporal lobe } \\
\text { epilepsy with } \\
\text { interictal } \\
\text { hallucinations and } \\
\text { personality change }\end{array}$ & $>20$ & yes & tied with rope & 15 & family & $\begin{array}{l}\text { History of violence; treatment not } \\
\text { affordable; fear that she will come to } \\
\text { harm; no-one to look after her }\end{array}$ & yes, temporary \\
\hline 13 & $\mathrm{~F}$ & 55 & $\begin{array}{l}\text { Dementia of } \\
\text { unknown aetiology } \\
\text { with behavioural } \\
\text { disturbance }\end{array}$ & 5 & yes & tied with rope & 5 & family & $\begin{array}{l}\text { Treatment not affordable; fear that } \\
\text { she will come to harm and come to } \\
\text { harm through accident; no-one to } \\
\text { look after her }\end{array}$ & yes, temporary \\
\hline 14 & M & 26 & $\begin{array}{l}\text { Schizophrenia and } \\
\text { suspected mild } \\
\text { mental retardation }\end{array}$ & 5 & no & wooden stocks & 3 & family & $\begin{array}{l}\text { History of violence; considered to be } \\
\text { dangerous to others; no-one to look } \\
\text { after him; treatment not affordable }\end{array}$ & yes \\
\hline 15 & $M$ & 35 & Schizophrenia & 15 & yes & wooden stocks & 6 & $\begin{array}{l}\text { Family and } \\
\text { community }\end{array}$ & $\begin{array}{l}\text { History of violence; considered to be } \\
\text { dangerous to others, no-one is } \\
\text { willing to look after him; refuses } \\
\text { treatment }\end{array}$ & no \\
\hline
\end{tabular}




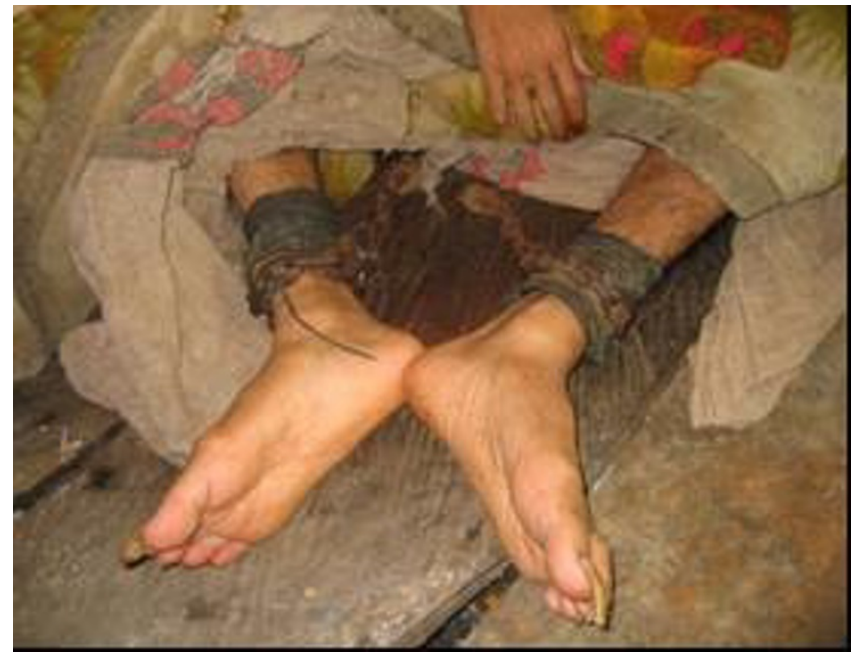

\section{Figure I}

Iron shackles are fixed to the wooden floor of a hut in which the person is confined.

When affordable treatment was offered almost all patients and families accepted the treatment. Third, despite the fact that many of the people had been in pasung for many years, all except two of the 13 who were released were still free at follow-up. The final and most important point is that achieving a favourable outcome for the majority of people in pasung required the development of a basic mental health system for Samosir.

The development of a basic mental health service had the support of the District Health Office and the District Parliament. An inpatient facility (one room with two beds) and an outpatient unit were established in the District

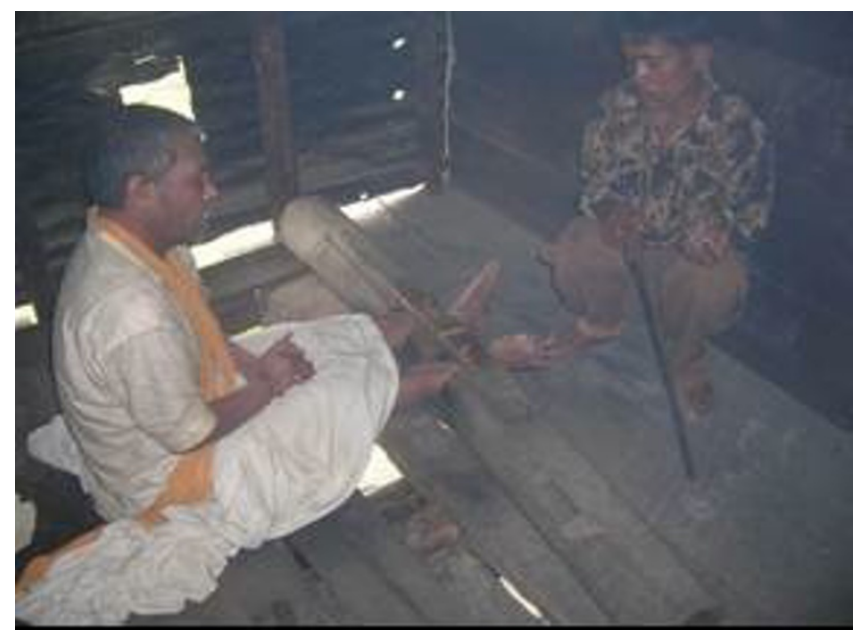

Figure 2

This man has his ankles in wooden stocks.

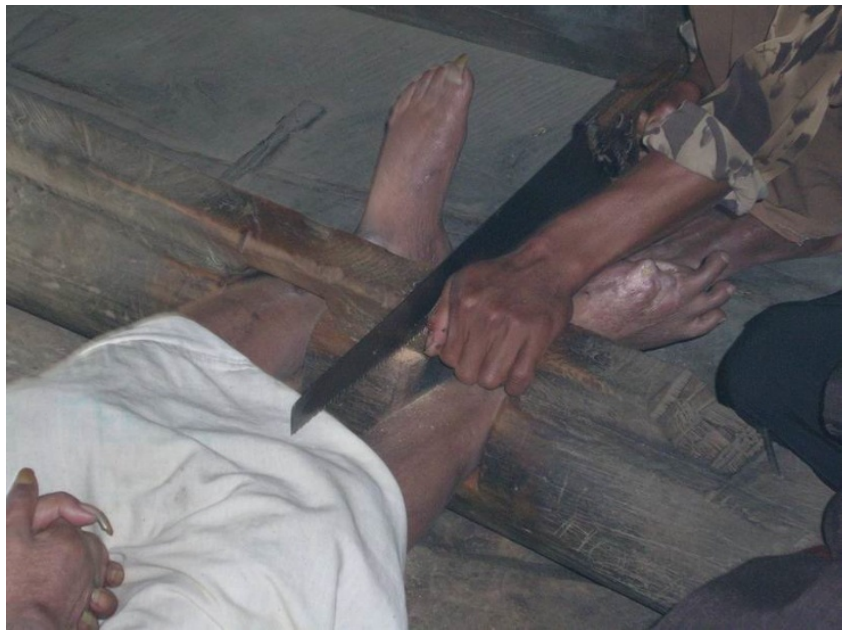

Figure 3

The man shown in Figure 2 being released from pasung.

General Hospital. The availability of psychotropic drugs was improved and training was carried out for the puskesmas doctors, nurses and midwives. Information was provided to village heads and the families of people with serious mental illness. A small mobile team, consisting of a general nurse, a midwife and a social worker from the District Health Office, supported by puskesmas doctors, nurses or midwives, was able to visit mentally ill people in their homes.

The phenomenon of restraint in the community of people with mental illness has been surprisingly neglected by researchers. There is a need for two types of research. The first is epidemiological research that will estimate the prevalence of the practice in different countries and different settings within countries, and that will clarify the role of a number of potential determinants, including poverty, potentially relevant social and cultural variables, and the availability and cost of psychiatric treatment and care. The second is ethnographic research that will elucidate the social and cultural meanings of the practice in a variety of settings and cultures, the relevance of beliefs about mental illness and psychiatric treatment, and the deep connections between poverty and pasung.

More surprisingly, the phenomenon has been largely neglected by human rights organizations and activists, and by development agencies and practitioners. The research that is referred to in the preceding paragraph will inform the development of international and local actions that have as their goal the eradication of this deeply offensive practice. 


\section{Conclusion}

The findings that are reported in this study demonstrate that the abuse of human rights that pasung represents is not a product of the callousness or ignorance of families and communities, or by refusal to accept psychiatric treatment, but may more correctly be attributed to neglect by governments of their responsibility to provide basic mental health services for people with severe mental illness. Systematic strategies need to be developed to eradicate this practice. This will require the collaborative participation of policy makers, service developers and managers and health professionals, development NGOs and bilateral agencies, and civil society organisations including those with a clear focus on promotion and protection of human rights of the most vulnerable in low resource settings. In the end, the only effective and sustainable strategy for eradicating the practice is to ensure that families and communities have affordable and equitable access to basic mental health services.

\section{Competing interests}

The authors declare that they have no competing interests.

\section{Authors' contributions}

HD collected the data, HM conceived and took primary responsibility for the writing of the manuscript, HM and HD jointly interpreted the data. Both authors have approved the final version of the manuscript.

\section{Acknowledgements}

The authors wish to acknowledge the willingness of people with mental illness and their families to accept psychiatric treatment when it was offered and of communities to provide the necessary support without which removal of pasung would have been difficult or impossible. We wish also to acknowledge the quick and constructive responses of the local parliament, general health services, and local journalists when these situations were brought to their attention.

This was an unfunded study.

\section{References}

I. United Nations General Assembly: Resolution 46/I 19: The protection of persons with mental illness and the improvement of mental health care. [http://www.un.org/documents/ga/res/46/ a46rl 19.htm]. Accessed 12/03/2008.

2. Broch HB: The Villagers' Reactions Towards Craziness: An Indonesian Example. Transcultural Psychiatry 200I, 38(3):275.

3. Beech H: Hidden away: Stigmatized, abandoned, often locked up, Asia's mentally ill are left to inhabit a living hell. [http:// www.time.com/time/asia/covers/501031/10/story.html]. Time Asia $3 / 1 \mathrm{I} / 2003$.

4. Chaining ban after India asylum fire [http://news.bbc.co.uk/// hi/world/south asia//4778I6.stm]. BBC News 7/8/200I.

5. Indian mental homes face closure [http://news.bbc.co.uk/2/hi/ south asia/l 479958.stm]. BBC News 8/8/200I.

6. Malik SB, Bokharey IZ: Breaking the chains. Psychiatric Bulletin 200I, 25:273-275.

7. Chang C-C: The chain London: Trolley; 2002.

8. Nair K-V: North Rand police probe 'church of chains'. [http:// www.wwrn.org/article.php?idd $=10862 \& \mathrm{sec}=\mid 3 \& \mathrm{con}=61]$. 3/8/2004.
9. Talley I: EU candidate Bulgaria 'beats, chains and cages mentally ill'. [http://findarticles.com/p/articles/mi qn4/58/is 20021012/ ai $\mathrm{n}$ 12657690]. The Independent 10/12/2002.

10. Albone T, Kehl S: Afghanistan's mentally ill chained up for cure. [http://www.timesonline.co.uk/tol/news/world/middle east/ articlel627003.ece]. The Sunday Times 8/4/2007.

II. Krosnar K: Mentally ill patients in central Europe being kept in padlocked, caged beds. British Medical Journal 2003, 327:1249.

12. Shackled day and night in Nigeria [http://news.bbc.co.uk/2/hi/ africa/76/30.stm]. BBC News 10/4/1998.

13. Rebuking the Devil [http://www.daylightatheism.org/2007/04/ rebuking-the-devil.html]. 6/4/2007.

14. Bauer W: Chain People. [http://www.wolfgang-bauer.info/pages/ reportagen/kettenmenschen/kettenmenschen e.html]. No date.

15. Minas $\mathrm{H}$, Cohen $\mathrm{A}$ : Why focus on mental health systems? Int J Ment Health Syst 2007, I(I):I.

16. Mentally III Man Spent Two Decades in Chains [http:// www.bio-medicine.org/medicine-news/Mentally-lll-Man-Spent-TwoDecades-in-Chains-7729-1/]. 2/12/2006.

17. Mentally-ill man in chains burnt to death in fire near Sandakan [http://www.encyclopedia.com/doc/IPI82624303.html]. New Straits Times 3/I0/200I.

18. Mentally ill man shackled for seven years [http://ia.rediff.com/ news/2001/aug/07men.htm]. Indo-Asian News Service Accessed 12/ $03 / 2008$.

19. 'Mentally ill' woman chained for 3 yrs [http://timesofindia.india times.com/India/Mentally ill woman chained for $3 \mathrm{yrs} /$ articlesho $2532321 \mathrm{cms}]$. The Times of India I I// I/2007.

20. Mentally ill children in pillories [http://www.truveo.com/Men tally-ill-children-in-pillories/id/2388987485]. Accessed I2/03/2008.

21. Dhanda A: The right to treatment of persons with psychosocial disabilities and the role of the courts. Int J Law Psychiatry 2005, 28(2): $155-170$

Publish with Bio Med Central and every scientist can read your work free of charge

"BioMed Central will be the most significant development for disseminating the results of biomedical research in our lifetime. "

Sir Paul Nurse, Cancer Research UK

Your research papers will be:

- available free of charge to the entire biomedical community

- peer reviewed and published immediately upon acceptance

- cited in PubMed and archived on PubMed Central

- yours - you keep the copyright 